\title{
Monitoring of wine aging process by electrospray ionization mass spectrometry
}

\author{
Monitoramento do processo de envelhecimento de vinho por espectrometria \\ de massas com ionização por eletrospray
}

\author{
Alexandra Christine Helena Frankland SAWAYA ${ }^{1,3 *}$, Rodrigo Ramos CATHARINO ${ }^{1,2}$, \\ Elizete Maria Pesamosca FACCO ${ }^{4}$, Aline FOGAÇA ${ }^{4}$, Helena Teixeira GODOY ${ }^{5}$ \\ Carlos Eugenio DAUDT ${ }^{4}$, Marcos Nogueira EBERLIN ${ }^{1}$
}

\begin{abstract}
The characterization of wine samples by direct insertion electrospray ionization mass spectrometry (ESI-MS), without pre-treatment or chromatographic separation, in a process denominated fingerprinting, has been applied to several samples of wine produced with grapes of the Pinot noir, Merlot and Cabernet Sauvignon varieties from the state o Rio Grande do Sul, in Brazil. The ESI-MS fingerprints of the samples detected changes which occurred during the aging process in the three grape varieties. Principal Component Analysis (PCA) of the negative ion mode fingerprints was used to group the samples, pinpoint the main changes in their composition, and indicate marker ions for each group of samples.
\end{abstract}

Keywords: electrospray ionization mass spectrometry; wine; aging process; Pinot noir; Merlot; Cabernet Sauvignon.

\section{Resumo}

A caracterização de amostras de vinho, sem pré-tratamento ou separação cromatográfica, por espectrometria de massas com ionização por eletrospray e infusão direta, em um processo denominado de fingerprinting, foi aplicado a várias amostras de vinho produzidas com uvas das variedades Pinot noir, Merlot e Cabernet Sauvignon, provenientes do Estado do Rio Grande do Sul, Brasil. Os fingerprints por ESI-MS das amostras detectaram mudanças que ocorreram durante o processo de envelhecimento para as três variedades de uvas. Análise de componentes principais (PCA) dos fingerprints em modo negativo foi usada para agrupar as amostras, salientar as principais modificações em composição e indicar os íons marcadores para cada grupo.

Palavras-chave: espectrometria de massas com ionização por eletrospray; vinho; processo de envelhecimento; Pinot noir; Merlot; Cabernet Sauvignon.

\section{Introduction}

In order to improve the quality of wines, research in viticulture and enology is carried out in several fronts. Improved grape quality and ripening, the selection of yeast inoculums and enzymes, control of the conditions during the malolactic fermentation as well as the aging process, are all important aspects of the production process. A sound knowledge of wine chemistry is also necessary. Polyphenols that are released in the must, during the fermentation and pressing processes from different parts of the berry, undergo condensation and polymerization during winemaking and wine aging (FLAMINI, 2003).

These compounds not only play an important part in the organoleptic characteristics of wine, but have also been related to the benefits of dietary wine consumption. Wine polyphenolics interact with reactive oxygen species and increase post-prandial total antioxidant capacity. These protective effects are especially displayed in people most likely to be under oxidative stress conditions, such as smokers and coronary heart disease patients
(COVAS et al., 2010). The phenolic compounds related to these effects can be divided into two main groups. Non-flavonoid phenols, such as gallic acid and caffeic acid, and stilbenes, like resveratrol, compose one group; whereas flavonoids, such as quercetin, cathechins and anthocyanidins, are the second group (GERMAN; WALTZEN, 2000).

Gas chromatography mass spectrometry (GC-MS) has been successfully used to study wine aroma. This technique, however, has not been successfully applied to the study of polyphenols, due to their low volatility. When derivatized to increase their volatility, their high molecular weight exceeds the mass range of most GC-MS systems (FLAMINI, 2003). Therefore, some of the first successful studies used hydrolysis and subsequent liquid chromatography (LC) methods to study wine phenolics. (WULF; NAGEL, 2000; HEBRERO et al., 1989) Later, the availability of effective interfaces for liquid chromatography mass spectrometric equipment (LC-MS) - some of which permitted multiple mass spectrometry experiments (MS/

1 ThoMSon Mass Spectrometry Laboratory, Institute of Chemistry, State University of Campinas - UNICAMP, CEP 13084-971, Campinas SP, Brazil, e-mail:franksawaya@terra.com.br

2 Department of Clinical Pathology, Faculty of Medical Sciences, State University of Campinas - UNICAMP, CEP 13083-970, Campinas, SP, Brazil

3 Department of Plant Biology, Institute of Biology, State University of Campinas - UNICAMP, CEP 13084-971, Campinas, SP, Brazil

${ }^{4}$ Food Science and Technology Department, Universidade Federal de Santa Maria - UFSM, CEP 97105900, Santa Maria, RS, Brazil

${ }^{5}$ Food Analysis Laboratory, Faculty of Food Science, State University of Campinas, UNICAMP, CEP 13083 862, Campinas, SP, Brazil

${ }^{*}$ Corresponding author 
MS or $\mathrm{MS}^{\mathrm{n}}$ ) - supplied powerful tools for the analysis of wine and its components (GAMOH; NAKASHIMA, 1999; LA TORRE, et al., 2006).

The characterization of whole samples by direct insertion electrospray ionization mass spectrometry (ESI-MS), without chromatographic separation, in a process denominated fingerprinting, is being applied to a constantly increasing array of analytes: natural products (MAURI; PIETTA, 2000; SAWAYA et al., 2004; ABREU et al., 2007); food and beverages (ARAÚJO et al., 2005; MOLLER; CATHARINO; EBERLIN, 2005, 2007; CATHARINO et al., 2005; DE SOUZA et al., 2007a,b); and petroleum and biodiesel (PORTER; MAYER; FINGAS, 2004; CATHARINO et al., 2007). It is a fast and reliable process especially applicable to the analysis of numerous samples and it is indicated for the qualitative distinction between samples. In the case of wine production, false information as to the type of grape, age and purity of wines could be used to mislead consumers. Therefore, a fast and robust method for the characterization of wine by grape variety and/or age could be applied to wine quality control.

Few studies of wine by direct insertion ESI-MS were carried out. Five samples of bottled wine were analyzed by direct insertion electrospray ionization Fourier transform mass spectrometry (ESI-FT-MS) in order to obtain the elemental composition of specific components (COOPER; MARSHALL, 2001). The authors noted that the negative ion mode fingerprint showed greater variety in the composition and abundance of components in the analyzed wines and a lesser amount of adducts, as well as higher resolution. Negative ion mode electrospray ionization mass spectrometry [ESI (-)-MS] is selective for compounds with acidic or phenolic sites, and therefore, adequate for studying wine phenols and polyphenols. Direct infusion ESI (-)-MS was used to analyze samples of must of five varieties of grapes and follow the transformations that occur during the malolactic fermentation process (CATHARINO et al., 2006). The ESI (-)-MS fingerprints clearly showed which samples were must and which came from the wine at the end of the malolactic fermentation, despite the variety of grape used. Furthermore, the addition of sugar or must to the wine could be easily detected in the fingerprints. In a more recent study, direct infusion ESI (-)-MS was used to characterize the oligosaccharides in two varieties of red wine (DUCASSE et al., 2010).

During aging, more subtle modifications occur, which are related to the final acceptability of mature wine. Changes in wine during maturation in new and used oak barrels or in tanks were followed using HPLC-UV and HPLC-MS, focusing on the anthocyanins (CANO-LOPEZ et al., 2010). Other authors have studied the effect of oxygenation on wine maturation using HPLC-UV and HPLC-MS (ATANASOVA et al., 2002). The question was whether direct infusion ESI (-)-MS (without chromatographic separation) would be capable of detecting differences in wine of different ages and different grape varieties. Therefore, in the present study, ESI (-)-MS is used to follow the transformations during the aging process of wine samples of three different varieties of grape, over a period of up to two years. Chemometric analysis of the negative mode fingerprints obtained was used to group the samples and pinpoint the main changes in their composition.

\section{Materials and methods}

\subsection{Samples of wine}

Samples of wine were obtained from 'Vinicola Velho Amâncio' winery near Santa Maria, in the State of Rio Grande do Sul, Brazil. Grape maturity was controlled by the winery (sugar content, acidity and $\mathrm{pH}$ ) and the following varieties were used: Pinot noir, Cabernet Sauvignon and Merlot. The alcoholic fermentation was considered terminated when sugar content was equal to zero. After the malolactic fermentation, the wine was cooled, filtered and five replicate samples of each wine variety were collected (CS, ME, PN) in 2004. After one year's aging (CS1, ME1, PN1), five replicate samples of each wine variety were again taken. For Pinot noir, five replicate samples were taken after two years of aging (PN2). Aging was carried out in bottles at $12{ }^{\circ} \mathrm{C}$. Aliquots of equal volumes of the PN1 and ME1 samples were mixed in the laboratory and analyzed (MIX).

\subsection{General experimental procedure}

Samples of wine were analyzed by direct infusion into the ESI source by means of a syringe pump (Harvard Apparatus) at a flow rate of $10 \mu \mathrm{L} /$ minute. Negative mode electrospray ionization mass spectrometry [ESI(-)-MS] fingerprints and negative mode ESI-MS/MS (low energy CID) spectra were acquired using a hybrid high-resolution and high-accuracy (5 ppm) Micromass Q-TOF mass spectrometer; capillary and cone voltages were set to $-3,000 \mathrm{~V}$ and $-50 \mathrm{~V}$, respectively, with a de-solvation temperature of $100{ }^{\circ} \mathrm{C}$. Aliquots of $10 \mu \mathrm{L}$ of each sample of wine were diluted in one $\mathrm{mL}$ of a solution containing $70 \%$ (v/v) chromatographic grade methanol (Tedia, Fairfield, OH, USA) and 30\% (v/v), deionized water, and $0.5 \%$ of ammonium hydroxide (Merck, Darmstadt, Germany). The negative ion mode was used because it is considered to be more adequate for the analysis of phenolic compounds in wine (COOPER; MARSHALL, 2001; CATHARINO et al., 2006).

\subsection{Statistical analysis of data}

Principal Component Analysis (PCA) was performed using the 2.60 version of Pirouette software, Infometrix, Woodinville, WA, USA. The mass spectra were expressed as the intensities of individual $[\mathrm{M}-\mathrm{H}]$ - ions (i.e. variables). Ions with relative intensities of less than $10 \%$ were not included. The data was preprocessed using auto scale and the PCA method was run.

\section{Results and discussion}

Figure 1 shows the representative ESI-MS fingerprints of wine samples $\mathrm{PN}, \mathrm{ME}$ and $\mathrm{CS}$ originated from the three varieties of grapes directly after the malolactic fermentation. The two diagnostic ions $\left(m / z 439-\mathrm{C}_{33} \mathrm{H}_{12} \mathrm{O}_{2}\right.$ and $m / z 559-$ a trimeric sugar $\mathrm{C}_{19} \mathrm{H}_{28} \mathrm{O}_{19}$ ) observed in all the wine samples at the end of the malolactic fermentation, mentioned in a previous study (CATHARINO et al., 2006), are also present in these samples. 
These ions were also observed in negative ion fingerprints of wine by Cooper and Marshal (2001) and had the following structures assigned: $m / z 439$ - CHO and $m / z 559$ - a trimeric sugar $\mathrm{CHO}$. Another oligosaccharide found in several samples of wine was the ion at $m / z 605$, found commonly in Merlot wine (DUCASSE et al., 2010). The ions of $m / z 115,133$ and 149 are also very intense in the fingerprints of wine before aging, they were identified as organic acids by the loss of $44 \mathrm{Da}$ in their MS/MS. Comparing their fragmentation pattern to previous studies; $m / z$ 133 was identified as malic acid, $m / z 149$ as tartaric acid, $m / z$ 191 as quinic acid, and $m / z 193$ as ferrulic acid (ROESLER et al.,

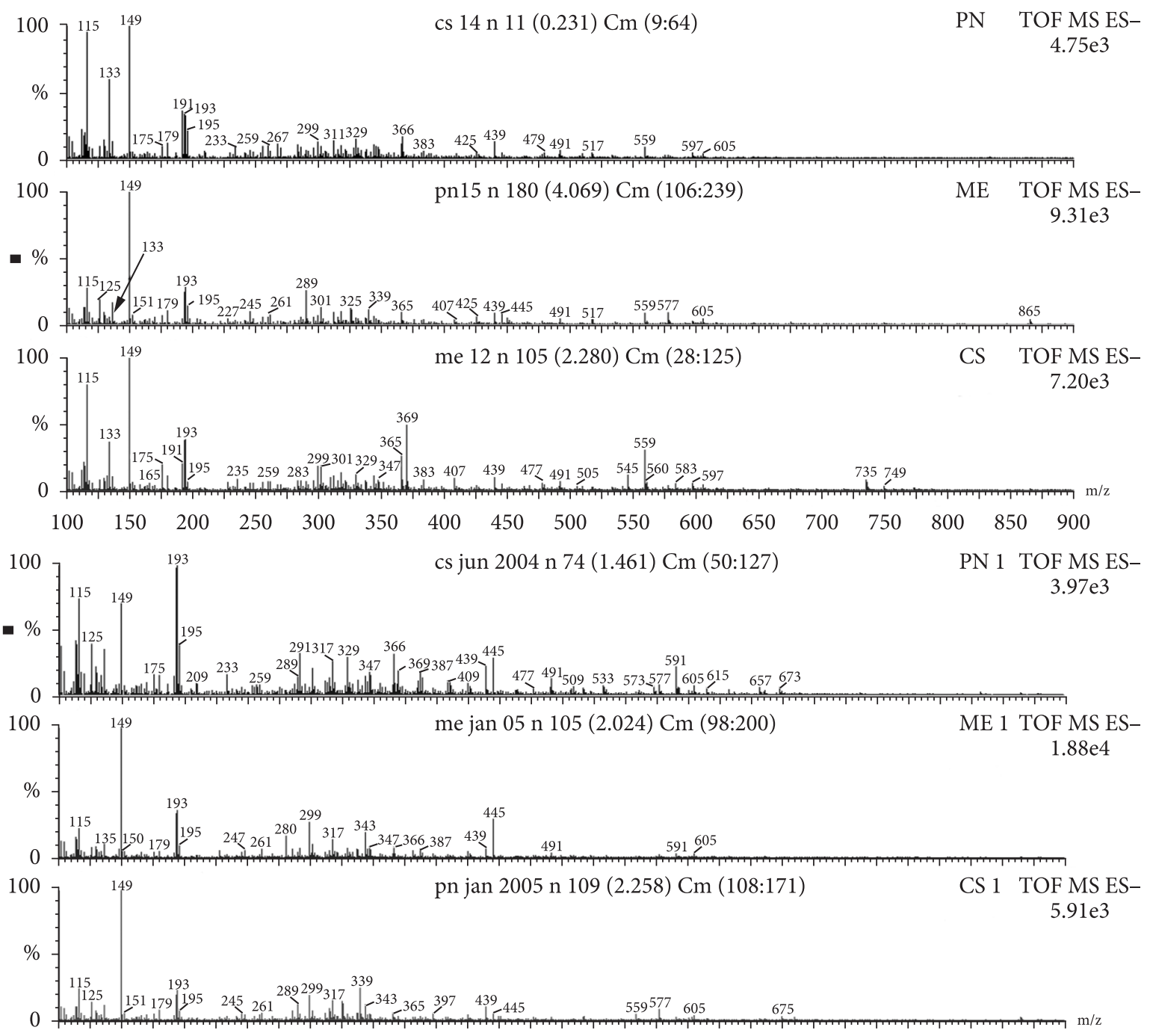

pn jan 2006 n 147 (2.893) Cm (47:290)

PN 2 TOF MS ES-
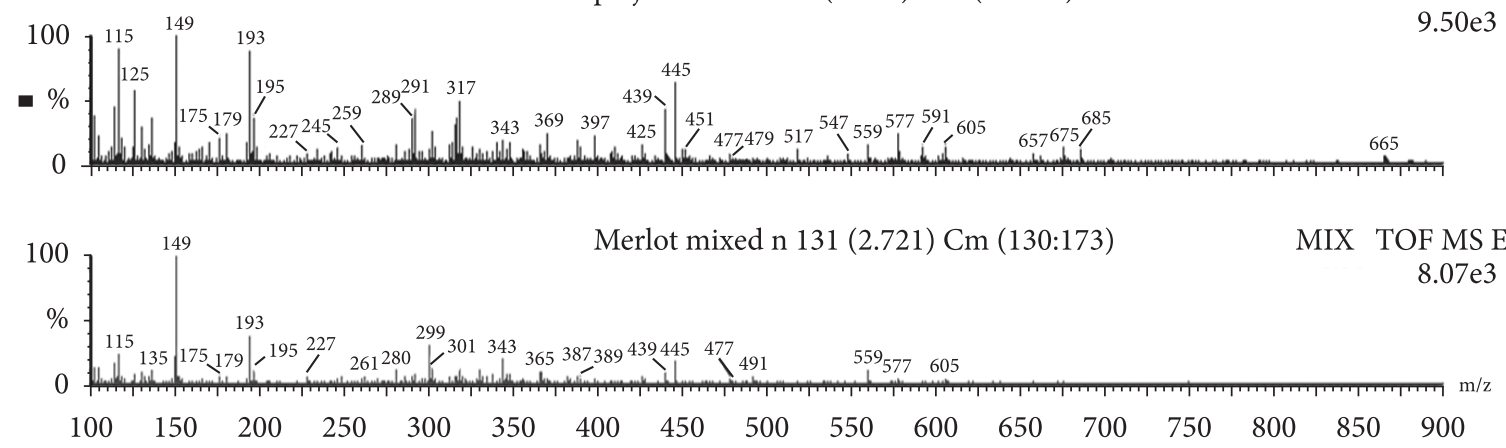

Figure 1. ESI-MS fingerprints in the negative ion mode of the wine samples directly after the malolactic fermentation (PN, Pinot Noir; ME, Merlot; CS, Cabernet Sauvignon), after one year's aging (PN1, Pinot Noir one year; ME1, Merlot one year; CS1, Cabernet Sauvignon one year) and after two year's aging (PN2, Pinot Noir two years). MIX is a mixture of ME1 and PN1. 
2007). These are phenolic compounds commonly found in red wine (VALENTÃO et al., 2007).

In the ESI-MS fingerprints of samples of one-year-old wines of the same three grape varieties (CS1, ME1, PN1), the diagnostic ion of $m / z 439$ can still be observed in all three varieties, but the ion of $m / z 559$ can be observed only in the CS1 fingerprint. The ions of $m / z 115$ and 133 are much less intense and $m / z 149$ (although still the most intense in the fingerprints of PN1and ME1) is relatively less intense in relation to other ions in the fingerprint. The ion of $\mathrm{m} / z 191$ (quinic acid) is less intense and the ions of $m / z 193$ (ferrulic acid) and $m / z 195$ are relatively more intense. The ions of $m / z 445$ and 317 are now clearly present in the fingerprints of the three varieties.

In the ESI-MS fingerprint of the two-year-old Pinot noir wine (PN2), the diagnostic ions of $m / z 439$ can still be observed, but not the ions of $\mathrm{m} / z 133$ and 191. Although the ions of $\mathrm{m} / z$ 115 and 149 are still the most intense in the fingerprints, they are now relatively less intense in relation to other ions in the fingerprint, such as $m / z 193,195,439$ and 445 .

The importance of these modifications during the aging process can be confirmed by the PCA. In Figure 2a, the scores plot, the samples were clearly grouped according to the variety of grape and age. The samples of young wine (CS, ME and PN) are all placed on the top left side of the plot, whereas the one-year-old samples are placed in the center and at the bottom
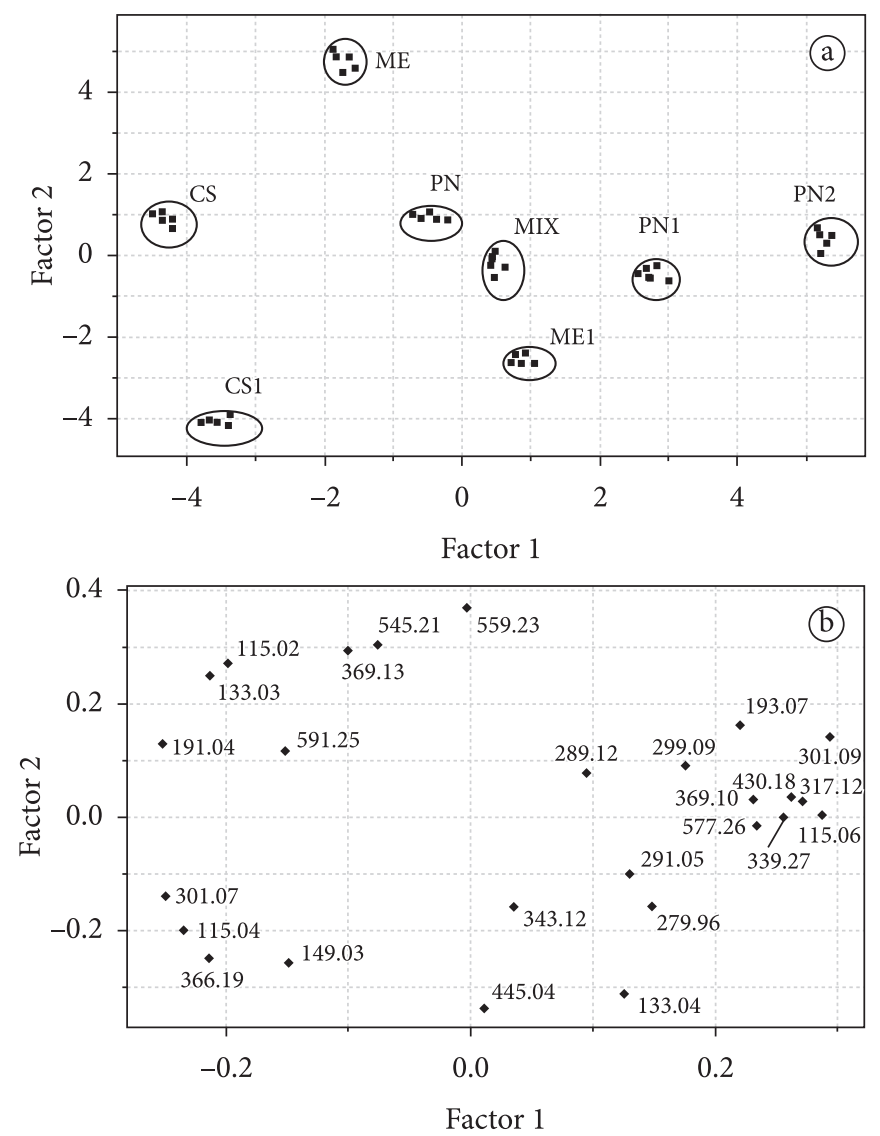

Figure 2. A. scores plot and B. loadings plot of the PCA analysis of the ESI-MS data for the wine samples (for abbreviations see Figure 1). The first two components (PC1 and PC2) retained $86 \%$ of the variation.
(CS1, ME1 and PN1), and the two-year-old sample (PN2) is on the right. The loadings plot (Figure $2 \mathrm{~b}$ ) indicates that the ions responsible for grouping the young wines are $m / z 115,133$ and 191, which are also evident in the fingerprints. As the wines mature, the decrease in the ions above, plus the increase in the intensity of the ions of $m / z 193,445$ and (to a lesser extent) $m / z 317$, which are also observed in the fingerprints, place these samples closer to the center. The two-year-old sample is placed on the right due to the relatively lower intensities of $\mathrm{m} / z 149$ and 115 and to the greater intensity of other ions of higher mass. The marker ions that denote the end of the malolactic fermentation $(\mathrm{m} / z 439$ and 559) are present in all fingerprints. These results characterize the transformation which occurs during the aging process, that is: the reduction of low mass organic acids and phenolic compounds and the formation of high mass polyphenols. Most studies of wine aging have focused on the changes that occur in oak barrels and under micro-oxygenation conditions (ALCALDE-EON et al., 2006; CANO-LOPEZ et al., 2010), which may not reflect the conditions of bottle-aged wines. Furthermore, in fingerprinting studies, the separation of different types of sample, due to characteristic fingerprints, is of greater importance than the identification of individual compounds. Nevertheless, the possibility of identifying compounds by MS/MS fragmentation can add further information about the samples.

The analysis of the fingerprints also indicates differences for each variety of grapes. For example, the fingerprints of Pinot noir wine contained the ions of: $m / z 289$ (catechin or epicatechin), $m / z 577$ (dimeric procianidin) and $m / z 865$ (trimeric procianidin), identified by comparison with literature (PÉREZ-MAGARIÑO et al., 1999; MONAGAS et al., 2003), as well as the ion of $m / z 245$, observed in the previous study (CATHARINO et al., 2006). Mixtures of one-year-old samples of Pinot noir and Merlot presented fingerprints as shown in Figure 1 MIX, contained ions observed in both varieties of wine. PCA placed these samples among those of the individual wines in the scores plot (Figure 2a), indicating that the fingerprint came from a wine of intermediate composition.

Other compounds identified in several samples comparing their MS/MS spectra to those found in the literature were: $m / z$ 227 - resveratrol, $m / z 301$ - quercetin, and $\mathrm{m} / z 317$ - myrcetin (LA TORRE et al., 2006). Flavonoids and other phenolic compounds, such as resveratrol, are important components of wine due to their beneficial antioxidant effects (COVAS et al., 2010).

\section{Conclusions}

Direct insertion ESI-MS fingerprints in the negative ion mode were able to detect transformations which occur during the aging process, as well as to detect variations in composition between wine made from different grape varieties and a mixture of two varieties prepared in laboratory. The analysis of large amounts of samples, in order to confirm the used grape variety and the age, is feasible through this fast and reliable process. Further studies with larger number of wine samples and other grape varieties of diverse geographic origin could be used to compile a library of fingerprints for the certification of origin of the individual samples. 


\section{Acknowledgements}

We are grateful to the State of São Paulo Research Foundation (FAPESP), to 'CAPES', and to the Brazilian National Council for Scientific and Technological Development (CNPq) for their financial support.

\section{References}

ABREU, I. N. et al. Characterization of the variation in the imidazole alkaloid profile of Pilocarpus microphyllus in different seasons and parts of the plant by electrospray ionization mass spectrometry fingerprinting and identification of novel alkaloids by tandem mass spectrometry. Rapid Communications in Mass Spectrometry, v. 21, p. 1-9, 2007. PMid:17330216. http://dx.doi.org/10.1002/ $\mathrm{rcm} .2942$

ARAÚJO, A. et al. Electrospray ionization mass spectrometry fingerprinting of beer. Analyst, v. 130, p. 884-889, 2005.

ALCALDE-EON, C. et al. Changes in the detailed pigment composition of red wine during maturity and ageing. A comprehensive study. Analytica Chimica Acta, v. 563, p. 238-254, 2006. http://dx.doi. org/10.1016/j.aca.2005.11.028

ATANASOVA, V. et al. Effect of oxygenation on polyphenols changes occurring in the course of wine-making. Analytica Chimica Acta, v. 458 , p. $15-27,2002$.

CANO-LOPEZ, M. et al. Oak barrel maturation vs. micro-oxygenation: Effect on the formation of anthocyanin-derived pigments and wine colour . Food Chemistry, v. 119, p. 191-195, 2010. http://dx.doi. org/10.1016/j.foodchem.2009.06.018

CATHARINO, R. R. et al. Characterization of Vegetable Oils by electrospray ionization mass spectrometry fingerprinting: Classification, Adulteration and ageing. Analytical Chemistry, v. 77, p. 7429- 7433, 2005. PMid:16285696. http://dx.doi. org/10.1021/ac0512507

CATHARINO, R. R. et al. Characterization of must and wine of six varieties of grapes by direct infusion electrospray ionization mass spectrometry. Journal of Mass Spectrometry, v. 41, p. 185-190, 2006. PMid:16382484. http://dx.doi.org/10.1002/jms.976

CATHARINO, R. R. et al. Biodiesel typification and quality control by direct infusion electrospray ionization mass spectrometry fingerprinting. Energy and Fuels, v. 1, p. 3698-3701, 2007. http:// dx.doi.org/10.1021/ef7003078

COOPER, H. J.; MARSHALL, A. G. Electrospray ionization Fourier transform mass spectrometric analysis of wine. Journal of Agriculture and Food Chemistry, v. 49, p. 5710-5718, 2001. PMid:11743752. http://dx.doi.org/10.1021/jf0108516

COVAS, M. I. et al. Wine and oxidative stress: Up-o-date evidence of the effects of moderate wine consumption on oxidative damage in humans. Artherosclerosis, v. 208, p. 297-304, 2010. PMid:19660752. http://dx.doi.org/10.1016/j.atherosclerosis.2009.06.031

DE SOUZA, P. P. et al. Electrospray ionization mass spectrometry fingerprinting of Brazilian artisan cachaça aged in different wood casks. Journal of Agricultural and Food Chemistry, v. 55, p. 2094-2102, 2007a. PMid:17305359. http://dx.doi.org/10.1021/ jf062920s

DE SOUZA, P. P. et al. Differentiation of rum and Brazilian artisan cachaça via electrospray ionization mass spectrometry fingerprinting. Journal of Mass Spectrometry v. 42, p. 1294-1299, 2007b. PMid:17902102. http://dx.doi.org/10.1002/jms.1197

DUCASSE, $M$. et al. Isolation of Carignan and Merlot red wine oligosaccharides and their characterization by ESI-MS.
Carbohydrate Polymers, v. 79, p. 747-754, 2010. http://dx.doi. org/10.1016/j.carbpol.2009.10.001

FLAMINI, R. Mass spectrometry in grape and wine chemistry. Part 1: polyphenols. Mass Spectrometry Reviews, v. 22, p. 218-250, 2003. PMid:12884388. http://dx.doi.org/10.1002/mas.10052

GAMOH, K.; NAKASHIMA, K. Liquid chromatography/mass spectrometric determination of trans-resveratrol inwine using a tandem solid-phase extraction method. Rapid Communications in Mass Spectrometry, v. 13, p. 1112-1115, 1999. http://dx.doi. org/10.1002/(SICI)1097-0231(19990630)13:12\%3C1112::AIDRCM621\%3E3.0.CO;2-3

GERMAN, J. B.; WALTZEN, R. I. The health benefits of wine. Annual Review of Nutrition, v. 20, p. 561-593, 2000.

HEBRERO, E. et al. Analysis of anthocianins by liquid chromatography - diode array spectroscopy in a hybrid grape variety. American Journal of Enology and Viticulture, v. 40, p. 283-291, 1989.

LA TORRE, G. L. et al. Direct determination of phenolic compounds in Sicilian wines by liquid chromatography with PDA and MS detection. Food Chemistry, v. 94, p. 640-650, 2006. http://dx.doi. org/10.1016/j.foodchem.2005.02.007

MAURI, P.; PIETTA, P. Electrospray characterization of selected medicinal plant extracts. Journal of Pharmaceutical and Biomedical Analysis, v. 23, p. 61-68, 2000. http://dx.doi. org/10.1016/S0731-7085(00)00264-8

MOLLER, J. K. S.; CATHARINO, R. R.; EBERLIN, M. N. Electrospray ionization mass spectrometry fingerprinting of whisky; immediate proof of origin and authenticity. Analyst, v. 130, p. 890-893, 2005. http://dx.doi.org/10.1039/b415422c

MOLLER, J. K. S.; CATHARINO, R. R.; EBERLIN, M. N. Electrospray ionization mass spectrometry fingerprinting of essential oils: Spices from the Labiatae family. Food Chemistry, v. 100, p. 1283-1288, 2007. http://dx.doi.org/10.1016/j.foodchem.2005.10.013

MONAGAS, M. et al. Monomeric, oligomeric, and polymeric Flavan-3-ol composition of wines and grapes from Vitis vinifera $\mathrm{L}$. Cv. Graciano, Tempranillo and Cabernet Sauvignon. Journal of Agriculture and Food Chemistry, v. 51, p. 6475-6481, 2003. http:// dx.doi.org/10.1021/jf030325+

PÉREZ-MAGARIÑO, S. et al. Various applications of liquid chromatography-mass spectrometry to the analysis of phenolic compounds. Journal of Chromatography A, v. 847, p. 75-81, 1999.

PORTER, D. J.; MAYER, P. M.; FINGAS, M. Analysis of Petroleum Resins Using Electrospray Ionization Tandem Mass Spectrometry. Energy \& Fuels, v. 18, p. 987-994, 2004. http://dx.doi.org/10.1021/ ef0340099

ROESLER, R. et al. Antioxidant activity of Anonna crassiflora: Characterization of major components by electrospray ionization mass spectrometry. Food Chemistry, v. 104, p. 1048-1054, 2007. http://dx.doi.org/10.1016/j.foodchem.2007.01.017

SAWAYA, A. C. H. F. et al. Electrospray ionization mass spectrometry fingerprinting of propolis. Analyst, v. 129, p. 739-744, 2004. http:// dx.doi.org/10.1039/b403873h

VALENTÃO, P. et al. Influence of Dekkera bruxellensis on the contents of anthocyanins, organic acids and volatile phenols of Dão red wine. Food Chemistry, v. 100, p. 64-70, 2007.

WULF, L. W.; NAGEL, C. W. High pressure liquid chromatographic separation of anthocyanins of Vitis vinifera. Journal of Agriculture and Food Chemistry, v. 48, p. 3999-3996, 2000. 